\title{
FINANCIEELE WETSVOORDRACHTEN IN DE VEREENIGDE STATEN.
}

Van het jongste jaarbericht van den Secretaris der Treasury is hier ter plaatse reeds een uitvoerig overzicht gegeven. 1) Ten vervolge daarvan worde thans vermeld, dat de Minister inderdaad een wetsontwerp heeft opgesteld met het doel om aan het door hem ontwikkelde plan uitvoering te geven, en dit door een zijner vrienden bij het congres is ingediend.

Het sluit zich bijkans geheel aan het oorspronkelijke plan aan. Slechts in één opzicht wijkt het daarvan af. Terwijl de Minister in zijn Bericht de uitgifte van nieuwe staatsbiljetten aanbeval tegren depot van zilver in het algemeen, maakt hij thans eene bepcrking. Volgens het wetsontwerp zou uitsluitend zilver worden aangenomen, dat af komstig is van de mijnon in de Ver. Staten zelven of wel als erts ingevoerd en in het land versmolten is.

Het doel dezer beperking is klaarblijkelijk om te voorkomen, dat van de aangeboden gelegenbeid tot plaatsing van nieuw verkregen zilver gebruik worde gemaakt om zilver, wat reeds elders in den geldomloop werd opgenomen of eenige andere aanwending vond, door ontmunting en omsmelting in baren naar Amerika te verplaatsen.

Voorts zou volgens een der Amerikaansche bladen, de Tribune, het de bedoeling van den Minister zijn om eventueel den prijs, waartoe het zilver door de munt der Ver. Staten over te nemen ware, zoo te stellen, dat die overeenkwam met den Londenschen prijs $\mathrm{m}$ in us de transportkosten van Amerika daarheen.

Natuurlijk zou ook hiermede beoogd worden, geen ander zilver naar de Ver. Staten te doen toestroomen om daar in den geldomloop te worden opgenomen, dan wat daarheen zịjn natuurlijken loop zou vinden.

En zeker zouden onder gewone omstandigheden de vermelde maatregelen bun doel niet missen. Doch bij den bestaanden stand van zaken is het waarschijnlijk dat ze weinig baten zullen om

ग) De Ecunumist $1890 \mathrm{blz} .23$ en $\mathrm{v}$. 
de misrekening te voorkomen, waaraan de uitvoering van het plari den Minister vermoedelijk zou blootstellen ten opzichte der door hem daaraan verbonden verwachtingen betreffende de verspreiding van het product der zilvermijnen.

Ongeveer tegelijkertijd met het bovengenoemde wetsontwerp is er een ander bij het Congres ingekomen, dat evenzeer de regeling van den geldomloop in de Ver. Staten tot onderwerp heeft. Het betreft de uitgifte van biljetten door de banken.

Dit wetsontwerp is afkomstig van den bekenden voormaligen Comptroller of the currency, den heer Jay Knox; het is in den Senaat ingebracht door den oud-Minister Sherman en in het Huis van Vertegenwoordigers door den voorzitter van de commissie voor bank- en muntzaken, den heer Dorsey.

Men kent den tegenwoordigen toestand. Het recht tot uitgifte van bankbiljetten is toegekend aan de Nationale banken tegen depot van Obligatien der Staatsschuld bij de Schatkist, in de verhouding van ds. 90 biljetten-nitgifte per ds. 100 nominaal bedrag der Staats-obligatien, en tegen eene bijkomende storting van $5 \mathrm{pCt}$. in geld aan de Schatkist als metaaldekking. De maximum circulatie, die onder dit stelsel bereikt is, valt in de eerste tachtiger jaren, toen - in $1881 / 83$ - de uitstaande biljetten ruim 360 millioen ds. beliepen. Doch sedert en inzonderheid in de allerlaatste jaren is dit bedrag aanmerkelijk verminderd. De voortdurende aflossingen en de hooge prijzen der Staatsobligatien hebben meer en meer de banken bewogen zich van die obligatien te ontdoen, al werd tevens het recht tot biljettenuitgifte evenveel ingekrompen. Intusschen vloeide uit den verkoop der gedeponeerde obligatien nog niet onmiddelijk de terugbetaling der biljetten voort. De biljetten konden in de wandeling blijven, doch de banken die het betrof, hadden dan het volle bedrag in geld bij de Schatkist te storten, en deze moest op hare beurt die gelden in kas houden tot dat de biljetten ter betaling opkwamen. Op 30 September 1.l. was ten gevolge van een en ander het totale bedrag der in omloop zijnde biljetten op ds. 203,662,732 verminderd, doch hierin zijn begrepen ds. $72,437,560$ waarvoor de volle metaaldekking bij de Schatkist aanwezig was. Met de 5 pCt. metaaldekking der overige biljetten maakte dit op gezegden datum eene totale metaaldekking van ruim 39 pCt: uit over de som der uitstaande biljetten, en was er dus op genoemden datum slechts voor een bedrag van ruim 120 millioen aan ongedekte bankbiljetten in omloop. Voorts is het 
te voorzien, dat binmen enkele jaren aan deze circulatie van fiduciair ruilmiddel voor goed een einde komt.

De heer Knox stelt nu voor, dat voortaan het recht van uitgifte ran biljetten aan de Nationale banken gegeven zal worden op de volgende voorwaarden:

maximum-uitgifte van iedere lank tot een bedrag van 75 percent van haar kapitaal;

depot bij de schatkist door de banken van ten minste 70 percent van de som der uittegeven biljetten in Obligatien Ver. Staten tot hun nominale waarde, en inet het recht om voor de helft dit depot te vervangen door gouden munt of muntmetaal, alsmede door zilver, dat tot zijn marktwaarde zou worden aangenomen, terwijl bij daling dier marktwaarde alsook bij daling der Ver. Staten obligatien onder pari het verschil zou moeten worden aangezuiverd, en bij gebreke van dien de uitgifte der bank rooveel zou worden ingekrompen door overbrenging van dat bedrag ten laste van het aflossingsfonds als ingesteld bij de wet van 1874 .

Voorts zou een fonds worden gevormd, waarin dadelijk zou worden overgebracht een bedrag van ds. 3 millioen, waarop ten minste is te begrooten de som der oude staats- on bankbiljetten, die verloren zijn geraakt en nooit ter betaling zullen opkomen, terwijl de gelden daarvoor gedeponeerd zijn, en dat zou oploopen door daaraan toe te wijzen de opbrengst van het recht van $\frac{1}{q}$ percent per halfjaar, dat over de bankbiljetten-circulatie moet worden betaald.

En eindelijk zou bepaald worden dat, zoo onverhoopt een bank insolvent zou worden en het ongedekte bedrag barer biljetten niet bij de liquidatie kon worden aangezuiverd, die biljetten volgens de bepalingen der bestaande wetgeving zouden worden ingelost en het bedraz zou worden overgeboekt ten laste van het vermelde fonds.

The Chronicle, dit voorstel hesprekende, betuigt zich daarmede tamelijk ingenomen. Het blad ziet er geen bezwaar in, dat aanvankelijk de nieuwe bankbiljetten voor bijkans 30 percent geen speciale dekking bij de Schatkist zouden hebben. De insolventies der nationale banken zijn steeds betrekkelijk zeldzaam geweest en het te vormen zekerheids-fonds zou spoedig oploopen, eerlang een belangrijke hoogte bereikt hebben.

De nieuwe regeling zou zeker gelegenheid geven om de bankbilletten circulatie aanzienlijk uit te breiden. Bij het tegenwoordige kapitaal der nationale banken - 612 millioen dollars - zou die tot 459 millioen kunnen worden opgevoerd. 
Het genoemde blad verwacht dat, ongetwijfeld, het hoofdzakelijk zilver en niet goud zon wezen, waaruit het depot van de bankbiljetten zou bestaan voor zoovcel het niet in Staatsobligatien werd gestort; doch dit - zegt het - ware geheel in overeenstemming met de algemeene begeerte in de Ver. Staten, die zich duidelijk verklaart voor de handhaving van het zilver naast het goud als wettig betaalmiddel. En, voegt het bij, daar het depot steeds naar de marktwaarde zou moeten worden angezuiverd, zou door die storting in geen geval de zekerheid der biljetten eenige vermindering ondergaan.

Mij dunkt intusschen dat het blad hier wel wat luchtig heenstapt over de gevaren en nadeelen, die aan de dekking met zilver van het fiduciaire ruilmiddel onder de tegenwoordige omstandigheden verbonden waren. En het laat 0 . a. geheel buiten beschouwing de risicos, welke daaruit voor de banken zelven zouden voortvlocien.

Een andere vraag is het, wat de Minister Windom van deze regeling der bankbiljetteneirculatie zal denken in verband met zijn wetsvoorstel. Naar de meening van den heer Knox zouden echter de beide voorstellen zeer goed te zamen uitgevoerd kunnen worden. De vraag naar zilver van de zijde der Nationale banken zou alleen dit gevolg kunnen hebben, dat de aanbiedingen daarvan an de munt zooveel zouden verminderen.

Eindelijk echter is er nog een ander punt dat hier in aanmerking komt. Naar de Chronicle zegt, zou de algemeene opinie in de Ver. Staten zich meer en meer verklaren tegen monopolies en privilegries van welken aard ook, die ten voordeele zouden strekken van bijzondere personen of instellingen, en het recht van uitgitte van bankbiljetten wel degelijk als een zoodanig privilegie beschouwen; men zal daarom iedere soortgelijke nieuwe regeling van zaken afkeuren en verlangen, dat de Staat van het recht tot uitgifte van biljetten ten eigen bate gebruik make.

Sedert het bovenstaande werd geschreven, is nader gebleken dat tegelijk met het wetsontwerp Windom, voorsteller het lid van den Senaat Morril, een contra-project van een ander lid van hetzelfde lichaam, den heer Cockrell, is ingekomen. Maar 't is overbodig daarvan den inhoud op te geven, want ook het Verslag. van het Financieele comité van den Senaat is reeds bekend geworden, en dit concludeert tot een regeling, die zich tamelijk wel aansluit bij het voorstel-Cockrell. 
In hoofdzaak zou deze hierop neerkomen:

dat de schatkist voortaan maandelijks zilver-aanknopen zou verrichten tot den prijs van den dag (mits beneden de muntwaarde) tot een bedrag van $4 \frac{1}{2}$ millioen dollar;

daartegen zouden staatsbiljetten worden uitgegeven, welke op vertoon inwisselbaar zouden zijn tegen wettig betaalmiddel en alsdan vernietigd zouden worden; voorts in betaling zouden aangenomen worden bij voldoening der belastingen en rechten, en bij de Nationale banken een bestanddeel zouden uitmaken der wettelijke reserve;

de Secretaris der schatkist zou gemachtigd zijn van het gekochte zilver zooveel to doen munten als noodig bleek ter voldoening der aanvragen tot inwisseling der biljetten.

Ook goud zou op soortgelijke voorwaarden aangenomen en behandeld worden, doch deze bepaling is uit den aard der zaak van ondergeschikt belang.

Het schijnt dat de zilver-partij in het Congres begrepen heeft, dat de voorstellen van den minister Windom op de van vele zijden geopperde bezwaren zouden afstuiten, en dat hieraan het ontwerp van het Financieele Comité, rapporteur het bekende lid van den Senaat, den heer Jones, te danken is. Dit zon daardoor dan toch gewomnen worden, dat de maandelijksche zilver-aankoopen van 2 op $4 \frac{1}{2}$ willioen werden gebracht.

G. M. B. 